\title{
INTELLIGENT DRIVERS OF SMART ECONOMY IN THE GLOBAL ECOSYSTEM
}

\author{
Iryna Kalenyuk' ${ }^{1}$, Liudmyla Tsymbal ${ }^{2}$, Iryna Uninets ${ }^{3}$
}

\begin{abstract}
Consistent and pervasive intellectualization and greening of the economy is manifested in the formation of Smart Economy, which is seen as a modern form of global ecosystem development. An important role in it is given to the latest technologies - information and communication technologies, which are becoming an important tool for "smart" management of processes and relationships between elements and actors at different levels in the global ecosystem. The research methodology is based on the systematization of theoretical approaches to understanding the concept of "Smart Economy", based on which the author's position on defining the essence, structure and key drivers of Smart Economy development is formulated. The aim of the article is to identify the main intellectual factors in the formation of the Smart Economy within the global ecosystem. Smart Economy is defined in a narrow (means of organizing economic relations and relationships within a certain locality) and broad sense, a system of economic relations based on the use of modern smart technologies, implementation of the principles of sustainability and social responsibility and subject to the creation of comfortable and safe conditions of life of citizens). The key processes of the formation of Smart Economy are: intellectualization, digitalization, greening, socialization, institutionalization and urbanization. The content of key intellectual drivers of Smart Economy and modern trends of their development are revealed: expansion of human role as a subject of social, cultural, ecological and moral values, subject of values of sustainable development, subject of social relations (property, management); increasing the importance and implementation in all spheres of social activity of important global and strategically important values of environmental protection, providing a comfortable environment (economic, social, political, business environment, etc.); results of intellectual activity (newest technologies, products) become an important factor of development and a tool for ensuring relationships and interactions between all components of the ecosystem; transformation of the management process: involvement of a wider range of actors, development of new mechanisms for the involvement of all actors and stakeholders in the decision-making process.
\end{abstract}

Key words: Smart Economy, intellectualization, greening, sustainable development, green development, smart development.

JEL Classification: F63, O18, O19, O44

\section{Introduction}

The society's development in modern era has the following features as an unprecedented increase in the role of knowledge and attention to social and environmental problems of humankind. The intellectualization processes in world economic development are strengthening. This caused emergence of the Smart Economy concept, which is the embodiment of a consistent and pervasive intellectualization and greening of the economy. In modern production process, the role of information-rich capital resources, goods, technologies, and highly qualified human resources has grown substantively. These highly qualified human resources not only have large amounts of modern knowledge, but also are capable to work with them, thus producing qualitatively new knowledge. The new economy's driver is the spread of new technologies. The new technologies play a new important role, thus performing certain important functions, included but not limited to managing the processes and relationships

\footnotetext{
Corresponding author:

${ }^{1}$ Kyiv National Economy University Named After Vadym Hetman, Ukraine.

E-mail: kalenuk@ukr.net

ORCID: https://orcid.org/0000-0003-1807-2849

${ }^{2}$ Kyiv National Economy University Named After Vadym Hetman, Ukraine.

E-mail: 1.tsimbal@ukr.net

ORCID: https://orcid.org/0000-0002-0873-9227

${ }^{3}$ National Pedagogical Dragomanov University, Ukraine.

E-mail: germanirina777@gmail.com

ORCID: https://orcid.org/0000-0002-1690-6590
} 
between different elements and actors, and shaping the global ecosystem's network. Therefore, the emergence of intelligent technologies that control other processes marks a new quality of economic life. In fact, this embodies the Smart Economy concept.

An urgent problem is the study of factors and drivers of such development of countries that are balanced with the natural environment. In the new social context, the issue is raised not only on innovation or ensuring innovative development, but also primarily on ensuring the ecosystems development. Therefore, this approach emphasizes that the economy should be percepted as an ecosystem, in which different areas of activity and their actors are balanced. Finding out this concept's features and the main trends of its manifestation is an urgent problem of modern world economics.

\section{Recent research and publications analysis}

The theoretical and methodological understanding of the essence of transformational processes occurring in the society is one of the most pressing problems in the scientific literature. Therefore, the emergence of such theories as post-industrial society, technotronic society, information society, and knowledge society can be considered as a reflection of this understanding. Thus, the key issues and the aspects of developing a new type of society and formation are studied in the works of D. Bell (Bell, 1973), V. Inozemtsev (Inozemtsev, 1998), M. Castells, F. Machlup (Machlup, 1966), A. Chukhno (Chukhno, 2005), D. Lukianenko (Lukyanenko, 2008), and others. Since the end of the last century, the topic of environmental protection has become relevant in scientific research; the concepts of sustainable development, green growth, and green economy were studied in the works by foreign and domestic economists A. Bowen, I. Gaidutskiy, I. Kalenyuk, J. Harris , D. Pearce, N. Stern, M. Jänicke, and others.

A new milestone at the beginning of the 21st century is the emergence of the concept of Smart Economy. This concept embodies spreading new smart technologies with the aim to manage efficiently the economic, social, and environmental processes. Moreover, such management should be based on increasing attention to social and environmental issues, which led to developing a new approach to the perception of economic phenomena and the processes, namely their study as elements of the ecosystem. The study of the Smart Economy formation is the basis for a significant number of scientific papers by J. Bruneckiene, J. Sinkiene (2014), L. Galperina et al. (2016), V. Maksimova (2011), V. Mazurenko (2014), R. Novotny et al. (2014), M. Heylin (2006), D. Kellner (2002), D. Held, A. McGrew (1999) etc. The study of the role of ICT in the formation of Smart Economy and smart cities was carried out in the works of N. Komninos $(2009,2011)$, M. Angelidou, N. Gountaras \& P. Tarani (2012).
In general, the concept of smart cities and their success has become very relevant because of the studies by R. Giffinger (2011), M. Angelidou (2016), A. Caragliu, P. Lombardi, S. Giordano, H. Farouh, \& W. Yousef (2012), K. Malthouse (2014), V. Kumar (2017), Krisna Adiyarta (2020), T. Nam \& T. A. Pardo (2011), H. Chourabi et al. (2012), H. Ahvenniemi et al. (2018), M. Eremia et al. (2016). Overall, understanding the Smart Economy concept despite the "obviousness" still needs in-depth economic research and justification.

Research methodology. The Smart Economy analysis is based, first of all, on the systematization of theoretical approaches to understanding this complex phenomenon. This allowed us to define the author's approach to understanding the essence and structure of Smart Economy as a key trend in the society at the present stage of its development. Also, there are determined the dominant processes of Smart Economy formation in the modern world economy as a global ecosystem The key drivers of Smart Economy development are identified, which allows us to reveal their content and define the current trends of their development.

The purpose of the paper is to identify the main intellectual factors in the Smart Economy development within the global ecosystem.

\section{The research findings}

Accelerated intellectualization is an important prerequisite for the Smart Economy development, which is manifested in increasing the innovation of production processes and their creative component, the constant increase in knowledge and information, development of innovative products, and the development of intellectual needs. The emergence of the "Smart" term is most often associated with the digitalization process deployment that is spread of information and communication technologies, together with their intellectual functions in all spheres of life, the spread of Internet of Things (IoT) and Artificial Intelligence (AI), networking, and network communication forms.

Thus, the Smart Economy development is influenced by the formation of Industry 4.0, the spread of technologies and their entry into the economic system, the constant growth of human comfort and environmental quality, and innovative networks development (Galperina, 2016). In addition, the globalization processes, which make it possible to maintain systemic governance and balance by coordinating the dependence of individual countries on the global development level, and key processes (including political, economic, financial, and social) are preconditions. This, therefore, involves expanding the openness of economic entities, liberalizing markets, creating structures that are resistant to external influences or capable to adapt quickly to the challenges of the economic, social, and cultural information environment (Maksimova, 2011). 
The transformation of the modern society's economic base is accompanied by the strengthening of the human centrism and the nature centrism processes, i.e. increased attention to social and environmental problems of social development. An important trend of modern global development is greening as increase of society's attention to environmental protection issues. Greening is realized in the system of ensuring ecological and economic interests, ensuring the integrity of natural systems, environmental protection, etc. Moreover, this trend is manifested not only in the declaration of important principles and goals, but also it becomes an essential component of all various types of social activities. In the implementation of any economic, social, business projects, consideration of the environmental context is increasingly becoming mandatory.

It is also worth noting such an important trend of modernity as socialization, i.e. the growing importance of solving social problems of the population. Socialization is aimed at ensuring the welfare of the population, compliance with pan-civilization values, formation and implementation of social values, etc.

Institutionalization is becoming a necessary accompanying process because the implementation of new ideas requires strengthening of government institutions and new communications between them. For instance, Audretsch et al. emphasizes the need to develop institutionalization of business ecosystems (Audretsch, 2021).

It is provided through the spread of new technologies and mechanisms of economic management, active participation of the state and other entities in the regulation of communications and various activities (research and development, innovation, entrepreneurship, etc.). The spread of ICT creates new opportunities for effective management, provision of effective communications and feedback, expansion of opportunities to include new entities in management processes. The concept of "e-government" appears as the embodiment of a new system of relations between the state and its institutions with citizens in various branches of government. Within the framework of e-government, with the help of ICT and the Internet, new wide opportunities are created for quick and direct access of citizens to public authorities, for the provision of quality services by state institutions and, thus, to protection of their interests.

The vast majority of scientists consider the concept of Smart Economy in a rather narrow sense, as part of a particular system - smart city. This is the definition of a system of a certain locality, all parts of which are connected though intelligent technologies, operate and are managed based on the principles of economic relevance, sustainability, and social responsibility. V. Kumar considers the smart city system as follows: Smart People, Smart Economy, Smart Mobility, Smart
Environment, Smart Living, Smart Governance (Kumar, 2017).

Indonesian scholars Indrawati, N. Azkalhaq, and H. Amani emphasize that Smart Economy "refers to an open, transparent, diverse economy that adds value to smart cities. SE will promote an efficient and effective business environment that supports and encourages innovation regardless of the outcome. It also provides a stable labour market with resources and the ability to adapt and make changes as needed. SE guarantees the success and economic growth of the city, as well as the livelihoods of its citizens" (Indrawati, 2018).

Lithuanian scientists J. Bruneckiene and J. Sinkiene define the main components of Smart Economy as follows: innovation and knowledge economy; learning economy; digital economy; competitive economy; green economy; network economy; socially responsible economy (Galperina, 2016).

In general, we believe that there are all reasons to consider Smart Economy in a narrow and broad sense. In a narrow sense, Smart-economy means a system of economic relations and interconnections within a certain locality, which is provided through the latest technologies based on the principles of sustainability and social responsibility and serves the purpose of creating comfortable and safe living conditions for citizens.

In a broad sense, we can interpret Smart Economy as a way of economic relations organization, which is based on using the latest smart technologies, implementation of the sustainability and social responsibility principles and subordinated to the goals of creating comfortable and safe living conditions for citizens. This, in fact, means that Smart Economy is considered an ecosystem, in which all major components are balanced. The key processes of Smart Economy formation are intellectualization, digitalization, greening, socialization, institutionalization, and urbanization (Figure 1):

The term "ecosystem" was first used in ecology when the English ecologist A. Tansley introduced it in 1935. Later, in 1942, in his classic work on the biology of lake in Minnesota, Raymond Lindeman defined an ecosystem as a group of living organisms (biocenosis) that adapted to living together in a certain habitat (biotope), forming a single whole with it. In economic research, J. F. Moore, who formulated the idea of business ecosystem, first used the term "ecosystem" in 1996. (Moore, 1997).

Since then, the approach to the study of economics as an ecosystem has become increasingly popular in science. For instance, C. Wessner emphasizes the importance of understanding the economy as a national innovation ecosystem. This approach allows to understand that this system is not fixed, it is evolutionarily growing in accordance with new needs and circumstances. This system is susceptible to changes provided by new policy initiatives. 


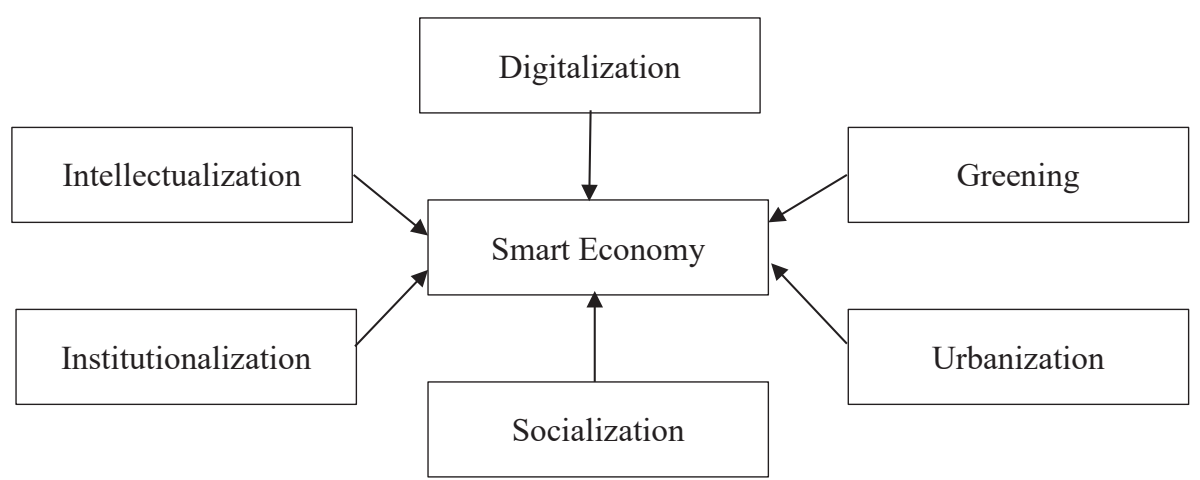

Figure 1. Key processes of smart economy formation

The ecosystem approach is based on the fact that complex relationships are formed between various participants in the innovation economy (individual entrepreneurs, corporate participants - such as big business and universities) and emphasizes the importance of incentives for different participants to create an innovation-friendly environment (Wessner, 2004). At the same time, there is no unity in academic literature in defining the range of major ecosystem participants.

The main participants in ecosystems are entrepreneurs, business support networks, corporations, financial experts and governments that integrate ICT/telecommunications innovation into their national development agendas. The International Telecommunication Union (ITU) considers ecosystem as a combination of the following components: business, finance, business support, the public sector, academia and the private sector (ITU-D Digital Innovation Ecosystems). The main problems in the digitalization policy implementation are lack of relevant policies, programmes, resources and know-how for innovators and producers of digital change in their communities; lack of proper systemic issues assessment of innovation ecosystem focused on ICT (business ecosystem, technological ecosystem and innovation ecosystem three engines of economic growth); lack of cooperation between stakeholders of the main growth factors for the creation of ICT projects for innovation and entrepreneurship (International Telecommunication Union (ITU), ICTs for a Sustainable World).

Summarizing these approaches, we can note the following important features of ecosystems: firstly, systemacity (i.e. the presence of a complete form of integration between various components); secondly, the presence of close relationships between components; thirdly, formation of an environment conducive both to the entities themselves and to the global space of human activity.

In current global ecosystem, new technologies not only provide important functions, but also allow to manage the processes and relationships between different elements and entities. In addition, the management is "smart", which requires a more precise definition - what exactly is "smartness", which actually gives name to a new type of economy.

J. Sinkiene et al. pays much attention to the study of "smartness" concept emergence. They agree with B. Hatt and S. Otto, who consider "smartness" a much broader phenomenon than just intelligence or awareness. "It is a social construction that includes cultural capital, social capital, innate intelligence, and creativity or ingenuity... associated with power" (Hatt, Otto, 2011). J. Sinkiene et al. argues that the social system smartness has such properties as "intelligence, erudition, digital nature, innovation, knowledge management, sustainability, networking and flexibility" (Sinkiene, 2014).

In our opinion, the concept of "smartness" has several important aspects. The first aspect is related to the growing importance of important global and strategic values in all spheres of social activity: preserving the environment, providing a comfortable environment (economic, social, political, business environment, etc.).

The second aspect in the modern world is the expansion of perception and human importance - not just as one of production factors. To ensure development of modern society, the necessary resource is not just a human resource as a carrier of working ability. Socioeconomic development of any entities and systems at all levels is ensured by the increasingly active inclusion of human as participant in social relations (property, management), bearer of social, cultural, moral values, and the values of sustainable development.

And the third important aspect is the transformation of the management process itself, which is about expansion of the range of participants and relevant change in its mechanisms and instruments. Management of various systems (economy, region, locality, and city) requires such instruments that ensure the "smart" nature of functioning, systematics of all relationships, focus on the sustainable development values. This system is ensured by involving the largest possible 
range of actors, which allows to consider their needs and interests. However, it is a difficult task to ensure effective management in the expansion context of the entity itself. In this situation, one cannot do without such an instrument as modern technology. Thus, the rapid development of ICT radically changes not only the technological basis, but also the entire system of economic relations in society. The rapid acceleration of all transactions transforms all interactions, mechanisms, and instruments for the economic activity implementation.

To the greatest extent, the smartness principle can be implemented at the locality level - a city, where there are real opportunities to link all components into a single "smart" ecosystem. Such an ecosystem includes human-centred approaches to creating and implementing smart city solutions, which create added value and become a collective good. It also necessarily requires ICT as a necessary instrument for "smart" management, but is not limited to available technological solutions. Under the influence of increasing attention to environmental and social issues, the latest technologies are already helping to provide smart management for all related processes.

In the academic literature on smart cities, the opinion on the rise of smartivism and the role of so-called smartivists as "an individual who steps forward by actively supporting the creation of a better place on a free basis" (Rise of the smartivist) is disclosed. The separation of smartivists is made by analogy with the "creative class" of R. Florida. The smartivist can act as a stand-alone expert or support smart city initiatives (e.g., free project consortia, new legal entities such as non-profit organizations, associations) to address specific issues (Ibid).

This expansion of the range of human qualities' functions and areas suggests that not only the role of human is growing, but also one's importance as a carrier of collective intelligence and management entity at different levels. According to Giffinger and his associates, collective intelligence is becoming the most effective success factor for smart cities. "Smart building based on human capabilities as the sum of individual players (bees) in a community (hive) allows to create and make decisions that lead to effective transformation of community into a strong ecosystem of smart city solutions."

Thus, an important feature and driver of a smart city success is the ability of city or community to use collective intelligence. "Collective intelligence provides a 360-degree perspective, covering all aspects of the community, as well as considering connections with neighbouring communities or regions" (Redefining the smart city concept: a new Smart city definition). The success of the smart city concept implementation in each case depends on the ability to combine in one stream the whole amount of smart initiatives, projects and solutions that are developed and implemented by a large number of different private and public entities throughout the city and in different strategic areas (Ibid).

As mentioned above, information and communication technologies are necessary tools for combining the whole amount of initiatives into a single effective management process. In modern world, they not only provide and accelerate communications, but also become intelligent, performing more and more intellectual and managerial functions. The concepts of the Internet of Things (IoT) (a system of managing things, devices, animals using the Internet) and Artificial Intelligence (AI) (the ability of an engineering system to acquire, process and apply knowledge and skills) are emerging. Along with the concept of ICT, other concepts are often used: digital technologies, NBICS - technologies (nano-, bio-, info-, cogno-, socio-technologies). According to I. Ardashkin, smart technologies are the broadest concept, which includes all different types of technology, they embody "a way of expressing the maximum possible development of technology, through which we identify the maximum limits of human capabilities, a kind of technological evolution's categorical level" (Ardashkin, 2018).

The term Internet of Things (IoT) was first used by $\mathrm{K}$. Ashton, one of the founders of the University of Massachusetts Auto-ID Centre. While working for Procter \& Gamble, he suggested that management use radio frequency tags to create a supply management system. Since then, physical item management systems have become more important parts of our lives. The most common definition of this concept is the following: "The Internet of Things is a network of physical entities that have built-in technologies that allow to interact with the environment, transmit information about one's condition and receive data from the outside" (Internet of Things).

The organization of remote control of various items requires the following necessary elements: items must have their own name ("label"), form a network and receive information from the outside using various controllers, sensors, Bluetooth and $\mathrm{Wi}-\mathrm{Fi}$, and be guided by a small built-in computer. The concept of "Smart Home" has emerged, and in it, the owner can remotely control the process of switching on and off all appliances and devices (signalling system, electricity and heating, home appliances).

Artificial intelligence is the creation of such systems that are able to perform intelligent functions: to acquire and process information, make decisions and perform certain functions. John McCarthy, the founder of programming and Lisp language, first used the term "artificial intelligence". Today, artificial intelligence systems are widelyused in space sphere, economics (hightech equipment, production management systems and demand forecasting), education (educational products 
and technologies, university rankings), medicine (diagnostics, recording of patients and their physical condition), politics (analysis of voter data and their preferences), retail (analysis of consumer behaviour), etc. The further spread of artificial intelligence systems also has certain obstacles due to ethical considerations, technical limitations, and dependence on a significant number of specialists and resources.

The above examples of ICT are evidence of rapid development of digitalization. However, the main impact of new technologies on the economy is that their spread is accompanied by networking processes, which generally lead to a new technical regime of interaction and the nature of relations between economic agents (Ustyuzhanina, 2018). The rapid networking development has become the core of the fact that the term "digital economy" (originated in the mid-1990s) was quickly replaced by the concept of "networking economy" (Parinov, 2002). Networking enables connection of remote entities to different networks. The modern world of economy is a truly global ecosystem in which all regions, structures, businesses, people and other entities are connected in a single network through ICT. Such reality not only accelerates all processes and transactions, but also transforms the whole system of relations (management, employment, property, etc.) and the economic structure at all levels.

The UN report "Future Possibilities" in 2020 named the rapid development of six areas as the main trend of future development: the Exabyte Economy, the Wellbeing Economy, the Net Zero Economy, the Circular Economy, the BioGrowth Economy, and the Experience Economy. All these areas are a direct aspect of Smart Economy development. With regard to ICT, the following trends are forecasted for the Exabyte Economy. After the pandemic, more and more people (+ 7\% annually) will work via the Internet. The Internet of Things (IoT) will develop: by 2023, there will be about 3.5 billion connections, compared to 1 billion in 2018. By 2025, Big Data revenue will exceed 90 billion USD, which is twice as much as in 2018.

5G technology will speed up data flow. Gradually, education, personalized healthcare, finance, and energy efficiency will shift online. After the pandemic, digitalization and automation will only grow. The cognitive computing market is projected to reach 49.3 billion USD by 2025 . The estimated economic impact of the Internet of Things is 11.1 trillion USD annually in 2025 . This is equivalent to $11 \%$ of world GDP, almost $40 \%$ of which can be obtained in developing countries. 5G will add up to 12.3 trillion USD to world output in ten years. Improving the health of people with chronic diseases through the connection of devices for remote monitoring by 2025 is estimated at 1.1 trillion USD per year (Future possibilities, 2020).

The "smart" nature of the new economy is manifested in spreading ecological and economic values, ensuring the integrity of natural systems, environmental protection, etc. Moreover, this trend is manifested not only in the declaration of important principles and goals, but it also becomes an integral part of all various social activity types of. In the implementation of any economic, social, or business projects, consideration of environmental context is increasingly becoming mandatory.

In the international community, this process is known as "greening", and in its understanding, different approaches can be distinguished. The term first appeared in 1970 in book by C. Reich "The Greening of America". Basically, he put in this concept a much broader meaning than attention to the environment. Nevertheless, in the beginning of the 21st century, this term was caught up and began to be widely used both in the scientific literature and in the media.

The turning point in increasing attention to environmental issues was the UN Conference in Rio de Janeiro (Brazil) in 1992 - the Earth Summit. Based on it, the governments of 178 countries adopted the Declaration on Environment and Development and the Declaration on Guiding Principles of Sustainable Development. In the same year, the Commission on Sustainable Development was established. Since then, many important global events have taken place, consistently promoting the ideas of sustainable development and environmental protection into politics and economics at various levels. Following the 20th anniversary of the Rio de Janeiro conference in 2002, a new Rio +20 conference was held, bringing together country leaders, thousands of private sector representatives, non-governmental organizations and other groups. A joint effort at this summit has developed a strategy on how to reduce insecurity, promote social justice, and ensure that all environmental measures are considered.

It was emphasized that the green economy is "one of the important tools available for achieving sustainable development... The institutional framework for sustainable development should beinclusive, transparent and effective and that it should find common solutions related to global challenges to sustainable development" (The future we want).

In 2008, the United Nations Environment Programme (UNEP) launched the Green Economy Initiative (GEI), a programme of global research and assistance at the country level to encourage politicians to support environmental investment. At the UN General Assembly in 2015, UNEP published "Uncovering Pathways towards an Inclusive Green Economy". Over the last decade, the concept of a green economy has become a strategic priority for many governments and intergovernmental organizations. In total, 65 countries have entered the path of an inclusive green economy and relevant strategies. By turning their economies into drivers of resilience, these countries are ready to 
address the major challenges of the 21 st century, from urbanization and resource scarcity to climate change and economic instability.

According to UNEP, the green economy includes three main concepts: low-carbon, resource-saving and socially inclusive development. In a green economy, employment and income growth are driven by public and private investment in infrastructure and assets that reduce carbon emissions and pollution, increase energy and resource efficiency, and prevent biodiversity loss (UN Environment Programme, Green Economy).

As a result of persistent work on the green economy implementation, the concept of an inclusive green economy emerged. An inclusive green economy is an economy that improves people's well-being and creates social justice, while reducing environmental risks and resource scarcity. An inclusive green economy is an alternative to modern dominant economic model, which enhances inequality, promotes overconsumption, causes resource shortages and poses widespread threats to the environment and human health. It is an opportunity to promote both sustainability and social justice as functions of a stable and prosperous financial system within a limited and fragile planet. This is the way to achieve the 2030 Agenda for Sustainable Development, and eliminate poverty while maintaining the environmental thresholds that underpin human health, well-being and development (what-inclusive-green-economy).

In its simplest terms, this economy is low-carbon, efficient and green in production, but also includes consumption and results based on sharing, circularity, cooperation, solidarity, sustainability, opportunities, and interdependence. It focuses on empowering national economies, using targeted and appropriate fiscal and social protection policies, and with the support of strong institutions specifically designed to protect social and environmental minimum levels.

Well-known economist Nicholas Stern in his work "The Economics of Climate Change" states "if we do not act, the total costs and risks of climate change will be equivalent to losing at least 5\% of world GDP now and forever. Given a wider range of risks and consequences, the loss estimate can increase up to $20 \%$ of GDP or more" (Stern, 2006).

Thus, we can trace the process of permanent growth of the world community's attention to environmental issues, which is confirmed by the growing number of events, publications, and action programmes at various levels. An example of "greening" policy practical implementation is the European Commission's policy to support farmers. Farmers receive direct green payments for the conservation of natural resources and the provision of public goods to the population at non-market prices. These direct environmental payments are made, if farmers follow three mandatory rules in favour of the environment: crop diversification (greater crop diversity makes soils and ecosystems more resilient); maintenance of permanent pastures (pastures support carbon sequestration, and protect biodiversity (environment)); allocation of $5 \%$ of arable land to the areas useful for biodiversity (such as environmental focus areas (EFAs), such as trees, verdant hedges or fallow land), which improves biodiversity and habitat conditions (Sustainable land use).

The green economy is considered as a way to achieve sustainable development. It requires shifting away from a resource-intensive model of growth, transforming consumption and production towards a more sustainable model, and increasing added value and reinvesting in resource-rich developing countries. To achieve a green economy, policy makers should strategically refocus consumption, investment and other economic activities to:

1) reduce carbon emissions, enhance energy and resource efficiency, prevent biodiversity loss and ecosystems, including efficient, low-impact technology development; buildings, transport infrastructure; investment in renewable energy; application of the life cycle approach; promotion of ecological goods and services; permanent source of materials; support and restoration of natural capital, consisting of land, soil, forests, fresh water, oceans, marine resources, wildlife and other components of biodiversity;

2) improve access to energy, food, clean water, biological resources, sanitation, public health and health care system, new jobs, health and social protection, ICT, training and education, including education for sustainable development and sustainable consumption promotion (Working towards a Balanced and Inclusive Green Economy).

In the context of general greening trend, there is also a term for new understanding of growth - green growth. Green growth is also defined as a policy that ensures "environmentally sustainable economic progress to promote low-carbon socially inclusive development" (OECD, 2011a). A number of academic papers are devoted to the study of green growth essence and factors (Jänicke, 2012; Bowen, 2011).

At the beginning of the new century, national and international efforts are intensifying to stimulate green growth as a new approach to increasing sustainable wealth. In 2009, the OECD, which promotes an integrated approach to addressing interconnected global challenges, began working on green growth as a way to address some of the world's most important challenges. In June 2009, the Ministerial Declaration on Green Growth was signed by all OECD member countries, which ensured the possibility of both greening and growth. OECD ministers approved the 
Green Growth Strategy (GGS) (OECD, 2011a) in May 2011. It suggests that green growth can open up new sources of wealth by encouraging greater efficiency and productivity of natural resources, innovation, and new markets for green technologies, goods, and services (Green Growth and Developing Countries).

The concepts of smart development and smart economic development are emerging (Dagiliene, 2020). L. Dagiliene et al. defines smart development as one that focuses on "achieving economic goals through the use of ICT, access to infrastructure and services through technological innovation." In turn, smart economic development so far includes three components (economic + social + environmental with the use of ICT); it is based on knowledge and soft skills aimed to use technology, innovation, infrastructure for economic development; emphasizes sustainable development of neoliberal economy and growth capitalization in the form of digital innovation (Ibid).

Greening is becoming a major trend in modern politics, firstly, at the global level and, secondly, at the national government level. The international practice of state support of the whole country life's ecological orientation is becoming more diverse and widespread (Yegorova, 2013). The introduction of economic incentives affects greening of investment and production of goods and services in general. This, in turn, forms new demand features - consumption of goods and services considering environmental component. Not only are the general and technical characteristics of products or services important to consumers, but also their impact on human health and the environment.

The chain reaction goes on: there is formation of environmentally conscious public opinion, and appropriate mentality. It has a wide range of manifestations in economic, public, social, and other activities. And most importantly - environmental guidelines should penetrate into human psychology, ecological consciousness of all social groups and entities should be formed. In addition, ecologically oriented consumer behaviour should be formed, when important values become conservation and economical use of resources in both production and consumption, transition to renewable energy sources, competent waste disposal, etc. An important aspect of the greening overall process is that all its manifestations are realized through new technology capabilities, in fact - information and communication technologies, nanotechnologies, biotechnology, etc.

\section{Conclusions}

Thus, a new paradigm of social development is being formed. This new paradigm incorporates the features with the focus on intangible wealth (such as intelligence, information, knowledge), social and environmental values based on the widespread use of modern technologies. It is with this approach that the main development subject is no longer the economy itself, but the ecosystem itself at all the same levels, including but not limiting to - micro level, meso level, macro level, and also regional, international, and global level.

The global ecosystem development is characterized by the development of such processes as intellectualization, digitalization, socialization, greening, etc., which together form the general trend of Smart Economy development. The key word of this new economy is "smart", which permeates all its components, basic relationships and processes, thus defining its essence. The general intellectualization process lies at the heart of this concept, which is a general trend of social and economic development. On the other hand, this general process intensifies and acquires new complex forms of manifestation.

The results of intellectual activity (such as advanced technologies, know-hows, products, and services) become an independent, but very influential factor in development, and even an important instrument for ensuring the relationships and interactions between all ecosystem components. The development of modern society requires more than just human resources as carriers of the ability to work. At present, the human perception is gradually expanded, the human importance is growing, and thus a person is being more actively included in all process as a bearer of social, cultural, and moral values, and as a bearer of sustainable development values. In turn, not just the carrier, but also as the subject of social relations (such as property, management), in which these values must be realized. That is why there is growing importance and implementation of important global and strategically important values in all spheres of social activity, which is next important factor in smartizing the economic development: preserving the environment, and providing a comfortable environment (economic, social, political, business environment, etc.).

All these circumstances update the next important driver of the Smart Economy in the global ecosystem. This is a transformation of the management process itself, to which new requirements are set, and for which new goals and objectives are made. An increasing number of actors are involved in the process of managing socio-economic development at any level. New mechanisms are being developed in order to involve all actors and stakeholders in the decisionmaking process. As a matter of fact, developing collective intelligence as the sum of the reasonable influence of all members of the community becomes a guarantee that all decisions will be "smart" and, in turn, that they will contribute to the formation of smart nature of the global ecosystem. 


\section{References:}

Ahvenniemi, H., Huovila, A., Pinto-Seppä, I., \& Airaksinen, M. (2018). "What are the differences between sustainable and smart cities?”. Cities, vol. 60, pp. 234-245.

Angelidou, M. (April 2016). Four European Smart City Strategies. International Journal of Social Science Studies, vol. 4, no. 4. Available at: http://dx.doi.org/10.11114/ijsss.v4i4.1364

Ardashkin, I. B. (2018). Smart-technologii kak fenomen: konceptualizacia podhodov i philosofskii analis. Javljajutsa li smart-technologii dejstvitelno umnimi? Vestnik Tomskogo universiteta. Philosofia. Sociologia. Politologia, vol. 43, pp. 55-68. Available at: https://cyberleninka.ru/article/n/smart-tehnologii-kak-fenomen-kontseptualizatsiyapodhodov-i-filosofskiy-analiz-yavlyayutsya-li-smart-tehnologii-deystvitelno-umnymi/viewer

Audretsch, D. B., Belitski M., \& Cherkas, N. (2021). Entrepreneurial ecosystems in cities: The role of institutions. PLoS ONE 16(3): e0247609. doi: 10.1371/journal.pone.0247609

Bell, D. (1973). The coming of post-industrial society: A venture of social forecasting. N.Y.: Basic Books. ISBN 0-465-01281-7

Bowen, A. (2011). The Green Growth Narrative: Paradigm Shift or Just Spin? Global Environmental Change 21(4). Available at: https://www.researchgate.net/publication/251624314_The_Green_Growth_ Narrative_Paradigm_Shift_or_Just_Spin (accessed 15 September 2020).

Bruneckiene, J. (2014). "The concept of smart economy under the context of creation the economic value in the city”, Public Policy and Administration, vol. 13, no. 3, pp. 469-482.

Caragliu, A., Del Bo, C., \& Nijkamp, P. (2011). “Smart cities in Europe”, Journal of Urban Technology, vol. 18, no. 2, pp. 65-82.

Chukhno, A. (2005). New economic policy (theoretical and methodological principles). Ukraine economy, vol. 7, pp. 15-22. (in Ukrainian)

Dagiliene, L., Bruneckiene, J., Jucevicius, R., \& Lukauskas, M. (January 2020). Exploring smart economic development and competitiveness in Central and Eastern European countries / Competitiveness Review: An International Business Journal incorporating Journal of Global Competitiveness. doi: 10.1108/CR-04-2019-0041

Future possibilities. Report 2020. Government of United States Emirates. UN. 2020. Available at: https://www.un.org/sites/un2.un.org/files/20200720_un75_uae_futurepossibilitiesreport.pdf

Galperina, L. P., Girenko, A. T., \& Mazurenko, V. P. (2016). The Concept of Smart Economy as the Basis for Sustainable Development of Ukraine. International Journal of Economics and Financial Issues, vol. 6(S8), pp. 307-314.

Hatt, B., \& Otto, S. (2011). A Demanding Reality: Print-Media Advertising and Selling Smartness in a Knowledge Economy, Educational Studies, vol. 47, pp. 507-526. doi: 10.1080/00131946.2011.621075

Held, D., McGrew, A., Goldblatt, D., \& Perraton, J. (1999) Global transformations. Oxford: Polity Press.

Heylin, M. (2006). Globalization of science rolls on. In Science \& Technology, vol. 84(48), pp. $26-31$.

Greengrowth (2011). Available at: http://www.greengrowth.org/index.asp

Sustainable land use (greening). Available at: https://ec.europa.eu/info/food-farming-fisheries/key-policies/ common-agricultural-policy/income-support/greening_en

Redefining the Smart city concept: a new Smart city definition. Available at: https://hub.beesmart.city/en/ strategy/towards-a-new-smart-city-definition

Rise of the smartivist. Available at: https:/ / hub.beesmart.city/smartivists/Rise-of-the-smartivist-the-importance-o What is an "Inclusive Green Economy"?

The future we want. Available at: https:// https://undocs.org/en/A/66/L.56

Green Growth and Developing Countries. Available at: https://www.oecd.org/development/environmentdevelopment/50559116.pdf

What is an "Inclusive Green Economy"? Available at: https://www.unep.org/explore-topics/green-economy/ why-does-green-economy-matter/what-inclusive-green-economy

Indrawati, Azkalhaq, N., \& Amani, H. (September 2018). Indicators to Measure Smart Economy: An Indonesian Perspective. doi: 10.1145/3278252.3278278

Inozemtsev, V. L. (1998). Outside the economic society. Moscow: "Academia” - "Science”, 342 p. (in Russian)

International Telecommunication Union (ITU). ICTs for a Sustainable World. Available at: https://www.itu.int/ en/sustainable-world/Pages/default.aspx

Internet of Things, IoT. Available at: https://www.it.ua/knowledge-base/technology-innovation/internet-veschejinternet-of-things-iot

ITU-D Digital Innovation Ecosystems. International Telecommunication Union. Available at: https://www.itu.int/en/ITU-D/Innovation/Pages/default.aspx

Jänicke, M. (2012). Green growth: From a growing eco-industry to economic sustainability. Energy Policy, pp. 13-21. Available at: https://www.sciencedirect.com/science/article/abs/pii/S0301421512003503

Kellner, D. (2002). Theorizing globalization. In Sociological Theory, vol. 20(3), pp. 285-305.

Kumar, M. V., \& Bharat, Daliya (2017). Smart Economy in Smart Cities. Smart Cities, Local Community and Socio-economic Development: The Case of Bologna, 12 p. 
Lukianenko, D. G. (2008). Global governance strategies. International economic policy, vol. 8-9. (in Ukrainian) Machlup, F. (1966). Production and dissemination of knowledge in the United States. Moscow: Progress, 462 p. (in Russian)

Maksimova, V. F. (2011). Smart (intellectual) economy: goals, objectives and prospects. Open education, vol. 3, pp. 63-71. Available at: https://cyberleninka.ru/article/n/smart-intellektualnaya-ekonomika-tseli-zadachi-iperspektivy/viewer (in Ukrainian)

Mazurenko, V. P. (2014). Implementation of network paradigm as a guarantee a highly competitive country. Actual problems of international relations, vol. 119, pp. 60-73.

Moore, J. F. (1997). The Death of Competition: Leadership and Strategy in the Age of Business Ecosystems. NY: Harper Business, pp. 6-7.

Nelson, R., \& Winter, S. G. (1982). An Evolutionary Theory of Economic Change. Cambridge, Mass.: Harvard University Press.

Novotny, R., Kuchta, R., \& Kadlec, J. (2014). Smart City Concept, Applications and Services. Journal of Telecommunications System \& Management, vol. 3, issue 2. doi: 10.4172/2167-0919.1000117

Parinov, S. I. (2002). On the theory of networked economics. Novosibirsk: IEOPP SO RAN.

Peters, T. (2010). In search of perfection. Lessons from America's Most Successful Companies. Moscow: Publishing house Alpina, 528 p. (in Russian)

Sinkiene, J., Grumadaite, K., \& Liugailaite-Radzvickiene, L. Diversity of theoretical approaches to the concept of smart city. 8th International Scientific Conference "Business and Management 2014" May 15-16, 2014, Vilnius, Lithuania Section: Smart Development. Available at: http://www.bm.vgtu.lt

Stern, N. (2006). Stern Review: The Economics of Climate Change. London: Grantham Research Institute on Climate Change and the Environment, 700 p. Available at: http://mudancasclimaticas.cptec.inpe.br/ rmclima/ pdfs/destaques/sternreview_report_complete.pdf

UN Environment Programme. Green Economy. Available at: https://www.unenvironment.org/regions/asia-andpacific/regional-initiatives/supporting-resource-efficiency/green-economy

Ustyuzhanina, E., Evsukov, S., \& Komarova, I. (2018). Network Economy as a New Economic System. European Research Studies Journal, vol. xxi, iss. 3, pp. 77-89.

Wessner, C. W. (2004). Entrepreneurship and the Innovation Ecosystem. Policy Lessons from the United States. The Papers on Entrepreneurship, Growth and Public Policy. Germany, p. 2. Available at: https://www.semanticscholar.org/ paper/Entrepreneurship-and-the-Innovation-Ecosystem-from-Wessner/968b28b0dc2c3f5c01e2107a71080fe eld886430

Working towards a Balanced and Inclusive Green Economy. A United Nations System-wide Perspective. Available at: https://issuu.com/christinadianparmionova/docs/working_towards_a_green_economy

Yegorova, M. S. (2013). Practica stimulirovanija perehoda k "zelenoj ekonomike": mezdunarodnij opit. Koncept, vol. 3, pp. 1651-1655. Available at: http://e-koncept.ru/2013/53333.htm 